\title{
Effects of Food Assistance Programs, Demographic Characteristics, and Living Environments on Children's Food Insecurity
}

\author{
Zhiming Qiu ${ }^{1}$, Chanjin Chung ${ }^{1}$ \\ ${ }^{1}$ Department of Agricultural Economics, Oklahoma State University, U.S.A \\ Correspondence: Chanjin Chung, Department of Agricultural Economics, Oklahoma State University, Stillwater, \\ Oklahoma, 74078, U.S.A.
}

Received: May 22, 2017

Accepted: June 21, 2017 Available online: June 21, 2017

doi:10.11114/aef.v4i4.2507

URL: https://doi.org/10.11114/aef.v4i4.2507

This research was supported by the USDA National Institute of Food and Agriculture (Hatch project, OKL02941) and the Division of Agricultural Sciences and Natural Resources at Oklahoma State University.

\begin{abstract}
The objective of this study is to examine impacts of food assistance programs, demographic characteristics, and socioeconomic status of households on children's food insecurity in U.S. Annual cross-sectional and pseudo-panel analyses with fixed effect regressions are conducted in this study using probit and truncated regressions. The simultaneous equation procedure is applied to address the endogeneity problem caused by the reverse influence of food insecurity on participation of food programs. Results show that some government-sponsored food programs are effective in alleviating the children's food insecurity problem, and demographic characteristics and living environments are important factors in determining the status of children's food insecurity. Our results also manifest the importance of considering the endogeneity problem of food program variables in evaluating the effectiveness of food programs.
\end{abstract}

Keywords: food program, food insecurity, living environment, demographic characteristics, pseudo panel data, simultaneous equation procedure

JEL Classification: I38, J18, Q18

\section{Introduction}

Food insecurity refers to the state of being limited or uncertain availability of nutritionally adequate and safe foods or being limited or uncertain ability to acquire acceptable foods in socially acceptable ways (Anderson, 1990). Many studies in the literature report the severity of food insecurity in U.S. (Cristofar \& Basiotis, 1992; Dixon, Winkleby, \& Radimer, 2001; Gundersen \& Gruber, 2001; Ribar \& Hamrick, 2003; Borjas, 2004; Coleman-Jensen, Nord, \& Singh, 2013). For example, Coleman-Jensen, Nord, \& Singh (2013) state that approximately $14.5 \%$ of U.S. households lived in food insecurity in 2012, meaning that approximately 17.6 million households had the problem of achieving enough or healthy food. In order to alleviate this food insecurity problem, the U.S. federal government has implemented several food assistance programs such as Supplemental Nutrition Assistance Program (SNAP), National School Lunch Program (NSLP), and the Special Supplemental Nutrition Program for Women, Infants, and Children (WIC) (see Reed \& Levedahl, 2010; Gleason \& Suitor, 2003; Aussenberg \& Colello, 2016 for details about food assistance programs in U.S.).

Food security is essential for children's health, physical activities, growth, intellectual development, and even future adult health status (Vereecken \& Maes, 2003). Few studies have examined impacts of public food programs on children's food insecurity. However, no clear evidence has shown the extent of effects of these programs, demographic factors and living environments of households on the probability of children's falling in food insecurity or the severity of their food insecurity. Some researchers study effects of food programs on household poverty. Rose (1999) states that the household poverty, determined by household income, indirectly measures the severity of people's hunger. Unlike studying poverty, the examination of children's food insecurity can help directly understand children's food diet and related health status. In 2012, a 59.1\% of households in poverty were not food insecure in U.S., which indicates that poverty and food insecurity are two different subjects (Coleman-Jensen, Nord, \& Singh, 2013). Figure 1 clearly shows 
the difference between children's poverty rate and children's food insecurity rate for the past 12 years from 2001 to 2012. Poverty rate of households and food insecurity rate of households look similar, but the poverty rate of children under 18 is much higher than the food insecurity rate of children under 18.

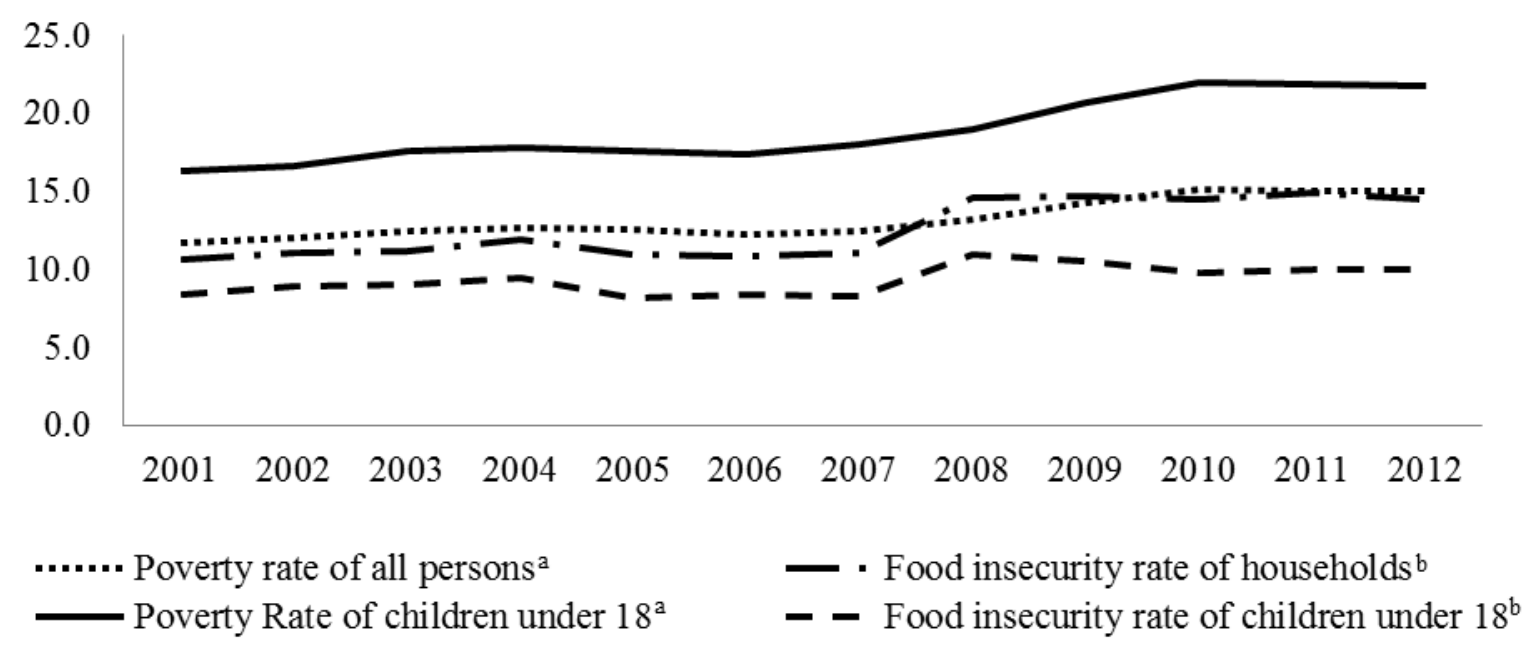

Figure 1. Poverty and Food Insecurity Rates

Source:

${ }^{a}$ Current Population Survey, Annual Social and Economic Supplements (U.S. Census Bureau, CPS-ASEC).

${ }^{\mathrm{b}}$ Current Population, Food Security Supplements (U.S. Census Bureau, CPS-FSS).

The objective of this study is to examine effects of food programs and household's demographics and socioeconomic characteristics on the status of children's food insecurity. Specifically, this study uses probit and truncated regression models to investigate whether or not the food programs, SNAP, NSLP, and WIC, decrease the probability of children's being food insecure and the severity of children's food insecurity, while effects of children's demographic and household's socioeconomic factors are also examined. The potential endogeneity problem, caused by the reverse influence of food insecurity on participation of food programs, is addressed by the simultaneous equation procedure. Both annual cross-sectional and pseudo-panel analyses with fixed effect regressions have been conducted in this study.

\section{Review of Previous Studies}

Recently, there have been numerous studies in the food insecurity literature. Cristofar \& Basiotis (1992) study the relationship between food intake and food insecurity for women and children and state that women's lower level of food intake is relevant to their food insecurity, but no such evidence is found from children. Dixon, Winkleby, \& Radimer (2001) find that adults from food insufficient families face various nutrition problems. Gundersen \& Gruber (2001) report the significant influence of the amount of savings on the low-income households' food insecurity. However, only a few studies focus on children's food insecurity. Weinreb, Wehler, Perloff, Scott, Hosmer, Sagor, \& Gundersen (2002) examine effects of food insufficiency on children's health and academic performance. They find that children in severe food insufficiency are more likely to suffer chronic illnesses and psychiatric distress. Alaimo, Olson, Frongillo Jr., \& Briefel (2001) study the relationship between food insecurity and child health and report that food insecure pre-school age children face more frequent colds than school-children do. Jyoti, Frongillo, \& Jones (2005) also report that food insecurity affects children's developmental outcomes, including academic performance, weight gain, and social skills.

Numerous studies in the literature investigate effects of government food programs on poverty or food insecurity. Bishop, Formby, and Zeager (1996) study impacts of SNAP on poverty in 1982 and 1990 using CPS data. Results show that SNAP is effective in reducing poverty for both years. Baker \& Grosh (1994) investigate households in Venezuela, Mexico and Jamaica with simulation experiments and report that geographically targeted programs are better than general food subsidies in reducing poverty. Jolliffe, Gundersen, Tiehen, \& Winicki (2005) conduct research on effects of SNAP on severity and incidence of children's poverty. The research finds that the incidence of children's poverty is not reduced much by food stamps, while the severity is significantly reduced. Wilde \& Nord (2005) estimate the impact of SNAP on food insecurity and report a strong effect of SNAP participation in reducing the food insecurity problem. A recent study by Nord \& Romig (2006) estimates effects of NSLP and Summer Food Service Program (SFSP) in food insecurity. The study shows that meals provided in the summer by NLSP and SFSP reduce the prevalence of food insecurity with hunger of the U.S. households. Jensen (2002) finds that the degree of food insecurity is correlated with 
the SNAP participation and concludes that labor market and program parameters have a relatively larger effect on more food insecure households than on others.

When evaluating food assistance programs, the variable representing a food program is endogenous rather than exogenous. That is, households with children who are suffering from food insecurity could also be more willing to participate in food programs compared to food secure households. Then, the estimation of effects of food programs on children's food insecurity is biased without properly addressing the endogeneity problem. Many studies have used the two-step simultaneous equation procedure to address the potential endogeneity problem (Mallar, 1977; Gundersen \& Oliveira, 2001; Kabbani \& Yazbeck , 2004; Huffman \& Jensen, 2008; Yen, Andrews, Chen, \& Eastwood, 2008; Ranney \& Gómez, 2010). In the first step, the probability of program participation is estimated with various predictors. Then, in the second step the predicted values of the endogenous variable from the first stage is included as one of explanatory variables in the food security equation. Gundersen \& Oliveira (2001) estimate the effectiveness of SNAP on food insecurity with and without controlling the endogeneity issue of the food program participation. When probit estimation is conducted without controlling the endogeneity problem, authors find that SNAP participation increases food insecurity. But, when the two-step model is estimated, SNAP doesn't have impact on food insecurity. Using a similar two-step model, Kabbani \& Yazbeck (2004) also find that participating in SNAP doesn't significantly reduce hunger for households with school age children, but participating in NSLP helps these households effectively. Huffman \& Jensen (2008) investigate the association of food stamp participation, labor market participation, and food insecurity using wage as an instrumental variable for equations of labor market participation and food stamp participation. In this study, unlike most previous studies, the Inverse Mill's ratio is added to the wage equation to address the labor force selection problem. Results indicate that the SNAP participation doesn't have a significant effect on food insecurity. Yen, Andrews, Chen, \& Eastwood (2008) also use the two-stage equation model, but instead of making food insecurity as a binary variable, the authors treat food insecurity as a censored variable. Findings from this study suggest that food stamp participation reduces the severity of food insecurity. Ranney \& Gómez (2010) estimate effects of SNAP and food insufficiency on the health of the elderly using an ordered probit estimation. The study finds that, after correcting for the endogeneity, the coefficient of SNAP participation on elderly health becomes statistically insignificant, whereas the food insufficiency significantly worsens elderly's health status. Nord \& Golla (2009) examine impacts of SNAP on food insecurity using panel data method while addressing the endogeneity. In their survey, same households are matched every two years to construct the panel data. This study finds the prevalence of food insecurity decreases among households participating in SNAP.

Although the previous studies mostly investigate effects of food programs on households' poverty or food insecurity, only few studies focus on children's food security (e.g., Alaimo, Olson, Frongillo Jr., \& Briefel, 2001; Weinreb, Wehler, Perloff, Scott, Hosmer, Sagor, \& Gundersen, 2002; Jyoti, Frongillo, \& Jones, 2005). Unlike these studies, our study examine effects of food programs, demographic characteristics, and parental or reference person's socioeconomic background on the status of children's food insecurity, specifically focusing on the probability of children being food insecure and the extent of children's food insecurity. We examine effects of three food assistance programs, SNAP, NSLP, and WIC, together, because, due to the existence of various children's food assistance programs, considering only one program could lead to biased results. To consider individual's behavioral changes over time, for the first time in the food insecurity literature, this study applies the pseudo panel data analysis to the Current Population Survey Food Security Supplements (CPS-FSS) data. The pseudo panel data are formed because the CPS-FSS data do not maintain repeated panel over time.

\section{Methodology}

\subsection{Probit and Truncated Regression Models}

This study uses binary and Rasch scale variables ${ }^{1}$ as dependent variables to represent children's food insecurity. The sample for the binary dependent variable model includes both food secure and insecure children and is used to estimate the probit model. The food secure children are dropped for the Rasch scale dependent variable model so that we can examine whether food assistance programs change the severity of children's food insecurity (for example, from severe to less severe food insecurity). Therefore, a truncated regression is conducted for this model. Probit and truncated regression models are written as:

$$
\begin{gathered}
F_{i}=\alpha_{0}+\sum_{j=1}^{J} \alpha_{j} P_{j i}+\sum_{k=1}^{K} \beta_{k} X_{k i}+v_{i} \\
R_{i}=\gamma_{0}+\sum_{j=1}^{J} \gamma_{j} P_{j i}+\sum_{k=1}^{K} \delta_{k} X_{k i}+\varepsilon_{i}
\end{gathered}
$$

where $F_{i}=1$ if food insecure, 0 otherwise; $R_{t}$ is the Rasch scale; $P_{t i}=1$ if the household $i$ with children (ages 0 through 17) participates in food program $j\left(j=\mathrm{SNAP}, \mathrm{NSLP}\right.$, and WIC), ${ }^{2} 0$ otherwise; $X_{k t}$ represents other explanatory variables representing children's age, gender, race, household income, residence location (metropolitan vs. 
nonmetropolitan), region, reference person's marital status, education, and employment status; and $v_{t}$ and $\varepsilon_{t}$ are errors.

A dummy variable is generated to indicate whether the child is at school age or at pre-school age: Schoolage $=1$ when a child is at school age (age 6 to 17), 0 otherwise. Note that WIC is only available to the pre-school age children up to 5 years old, and NSLP is only for the school age children. Children's race includes: White $=1$ when a child is white and not Hispanic, 0 otherwise; Black $=1$ when a child is black and not Hispanic, 0 otherwise; Hispanic $=1$ when a child is Hispanic, 0 otherwise. Family structure variable includes: Married couple $=1$ when a child lives with a married reference person, 0 otherwise; Single mother $=1$ when a child lives with a single-mother reference person, 0 otherwise; Single father $=1$ when a child lives with a single-father reference person, 0 otherwise; Other household $=1$ when a child lives with an unrelated reference person, 0 otherwise. For household income variables, ${ }^{3}$ Income $1=1$ if a child lives in a household with the income-poverty ratio (i.e., income/poverty) smaller than 1.0, 0 otherwise; Income $2=1$ if a child lives in a household with the income-poverty ratio greater than or equal to 1.0 and smaller than $1.3,0$ otherwise; Income $3=1$ if a child lives in a household with the income-poverty ratio greater than or equal to 1.3 and smaller than $1.8,0$ otherwise; Income $4=1$ if a child lives in a household with the income-poverty ratio (i.e., income/poverty) greater than 1.8, 0 otherwise. Residence of child indicates whether a child lives in metropolitan area or non-metropolitan area. ${ }^{4}$ Residential region includes Northeast, Midwest, South, and West. Education of the reference person is also expected to affect a child's food insecurity. Four education variables considered in this study include: High school $=1$ when a child lives in a household with a reference person who has a high school degree, 0 otherwise; Some college $=1$ when a child lives in a household with a reference person who has some level of college education, 0 otherwise; Bachelor $=1$ when a child lives in a household with a reference person who has a bachelor degree, 0 otherwise; Graduate $=1$ when a child lives in a household with a reference person who has a graduate degree, 0 otherwise. A dummy variable to represent the reference person's employment status is also generated and included in the model. Employment $=1$ when a child lives in a household with the reference person who is employed, 0 otherwise.

\subsection{Probit and Truncated Regression Models with Simultaneous Equation Procedure}

As discussed earlier, $\boldsymbol{P}_{f^{t}}$ in (1) and (2) are endogenous because children's food insecurity could be affected by the participation of food programs, but the participation of food programs could also be affected by children's food insecurity. The endogeneity makes the parameters estimated from (1) and (2) biased and inconsistent. To address the endogeneity problem of food program variables, a two-stage simultaneous equation procedure has been suggested in the literature (e.g., Mallar, 1977; Maddala, 1983; Gundersen \& Oliveira, 2001; Huffman \& Jensen, 2008).

For the two-stage procedure, the first step is to estimate a reduced form equation and calculate predicted values from the estimated equation. A probit model for the first step is specified as:

$$
P_{j i}^{*}=\pi_{j 0}+\sum_{l} \pi_{j l} X_{l i}^{\ell}+v_{j i}^{t}
$$

where $P_{j t}^{*}$ indicates the probit prediction of individual $i$ for program $j ; X_{k t}^{t}$ represents instrument, demographic, and socioeconomic variables; and $v_{j t}^{\prime}$ represents error terms. Instrumental variables used for the estimation of SNAP participation in equation (5) are from SNAP policy database (USDA/ERS), which include biometric technology, outreach spending, and expanded categorical eligibility. Biometric technology is the change in biometric information (e.g., fingerprinting) requirement policy, which can affect SNAP participation by increasing the cost of participation (Ratcliffe, McKernan, \& Zhang, 2011). Outreach spending is the sum of federal, state, and grant outreach spending and is expected to increase participation of SNAP. Expanded categorical eligibility is the increase in the maximum income limit to SNAP applicants and is expected to increase the participation. Variables used to estimate NSLP and WIC participation are limited only to demographic and socioeconomic variables because similar instrumental variables are not available.

The second step is to estimate the full equations with the predicted values from the first step as:

$$
\begin{aligned}
& F_{i}^{* *}=\alpha_{0}+\sum_{j=1}^{J} \alpha_{j} P_{j i}^{*}+\sum_{k=1}^{K} \beta_{k} X_{k i}+v_{i} \\
& R_{i}^{* *}=\gamma_{0}+\sum_{j=1}^{J} \gamma_{j} P_{j i}^{*}+\sum_{k=1}^{K} \delta_{k} X_{k i}+\varepsilon_{i}
\end{aligned}
$$

Estimates of (4) and (5) are compared with estimates of (1) and (2) to show the importance of addressing the endogeneity problem of food program participation variables. Estimates of (4) and (5) are inefficient if the error variances of these equations are heteroscedastic. The White test confirms the heteroscedasticity, and therefore, the GLS procedure is used to estimate (4) and (5). 


\subsection{Pseudo Panel Data Analysis}

In addition to the cross sectional data analysis for each year, this study also conducts the pseudo panel data analysis. In general, the panel data analysis is superior to the cross sectional data analysis because the panel analysis allows one to consider dynamic behavior of individuals over time. Another advantage of the panel data analysis is that it can control for unobserved factors for the regression. When unobservable factors are correlated with explanatory variables, the regression model cannot be identified by the independent cross sectional data (Collado, 1998). When the panel data analysis is conducted with a fixed effects model specification, unobserved factors in the children's food insecurity equation can be controlled.

However, one major limitation of applying the panel analysis to this study is that the CPS-FSS survey does not collect repeated panel data. For our sample period, the percentage of the same individuals being identified for two consecutive years is only about $50 \%$. The survey has probably been designed such a way to avoid the attrition bias. Therefore, the question is how to conduct a panel data analysis when one has access to only independent cross-sectional data without real panel data. A pseudo panel data analysis is used in this study, which creates cohorts who share same characteristics and uses the average values of the cohorts to replace individuals. The average values of cohorts can be used in the same way as individuals in panel data to estimate the relationship between the food programs and children's food insecurity.

Many researchers suggest that characteristics included in the cohort creation should be time-invariant, and that the cohorts should have sufficient variation across years so that parameters can be estimated. In many studies, birth year has been frequently used to create cohorts because birth year is an obvious time-invariant variable (Deaton, 1985; Verbeek \& Nijman, 1992; Moffit, 1993). But in our study, birth year does not appear to be a proper choice because cohort size shows big difference across birth year groups, which can cause large measurement errors. To make the cohort size as even as possible, cohorts are created based on: (1) reference person's education: less than high school, high school, and over some college; (2) child's gender: male and female; (3) child's race: white who are not Hispanic, black who are not Hispanic , Hispanic, and other; and (4) child's residence region: Northeast, Midwest, South, and West. Although reference person's education and region of child's residence are not strictly time-invariant, over $90 \%$ of households identified in two consecutive years in the dataset show same reference person's education and no migration across regions. Then, the total number of cohorts is $3 \times 2 \times 4 \times 4=96$. The number of cohorts needs to be determined carefully. If the number of cohorts becomes larger, the size of each cohort becomes smaller. However, no research has shown exactly how large the cohort size should be or how large the number of cohorts should be. Measurement error could be a potential problem in the pseudo panel data analysis. However, as long as the size of each cohort is sufficiently large, the measurement error can be ignored (Deaton, 1985; Verbeek \& Nijman, 1992), and many studies do not consider the measurement error in their analyses (e.g., Moffit, 1993; Blundell, Browning, \& Meghir, 1994; Bernard, Bolduc, \& Yameogo, 2011). The size of cohorts in our sample is at least 50, and therefore we do not take into account the potential measurement error problem in our pseudo panel analysis.

A fixed effects model is specified for the pseudo panel data analysis as:

$$
\begin{gathered}
\bar{F}_{c t}=\alpha_{0}+\sum_{j=1}^{J} \alpha_{j} \bar{P}_{j c t}+\sum_{k=1}^{K} \beta_{k} \bar{X}_{k c t}+u_{c}+v_{c t}, c=1, \ldots, C ; t=1, \ldots, T \\
\bar{R}_{c t}=\gamma_{0}+\sum_{j=1}^{l} \gamma_{j} \bar{P}_{j c t}+\sum_{k=1}^{K} \delta_{k} \bar{X}_{k c t}+\theta_{c}+\varepsilon_{c t}, c=1, \ldots, C ; t=1, \ldots, T
\end{gathered}
$$

where $\bar{F}_{c t}, \bar{R}_{c t}, \bar{P}_{f c t}, \bar{X}_{k c t}$ represent food insecurity status, Rasch scale score, predicted participation of food programs (from (3)), and other explanatory variables representing children's demographic factors and their living environments for cohort $c$ at time $t$, respectively; $u_{c}$ and $\theta_{c}$ represent unobservable cohort effect; $v_{c t}$ and $\varepsilon_{c t}$ are errors. Pseudo panel data use average values of cohorts for each variable. However, the binary dependent variable in equation (6), $\bar{F}_{c t}$, is created by the following three steps. First, the average number of positive responses to food security-related questions is calculated for each cohort. Then, using the average number of positive responses, the threshold number is determined to maintain approximately the same proportion of the food insecurity as the initial sample with individual children. Finally, the food insecurity status for each cohort is determined by comparing the average number of positive responses and the threshold value. For example, the food insecure children account for $9.9 \%$ in 2001 from the initial sample. To maintain the $9.9 \%$ level of food insecurity, the threshold level for the positive responses should be 0.95 . Therefore, if the number of positive answers from a cohort is greater than 0.95 , we consider the cohort to be in food insecurity. The average Rasch scale value for each cohort, $\bar{R}_{c t}$, is used as the dependent variable for the Rasch scale model. It should be noted that the pseudo panel data analysis also addresses the endogeneity problem using the two-step simultaneous equation procedure. 


\section{Data}

Data used in this study are obtained from the Current Population Survey-Food Security Supplements (CPS-FSS) conducted by the U.S. Census Bureau. The CPS collects a mass of high quality data on labor force activity such as employment status and income, and personal demographic characteristics such as age, gender, race, education, and marital status. The FSS provides annual statistics concerning food access and adequacy, food spending, and food assistance programs. The FSS survey has been conducted each December since 2001, and about 60,000 households and 150,000 individuals are surveyed every year; approximately $33 \%$ of whom are children (ages 0 through 17). This study uses household data with children from December 2001 through December 2012.

In the food insecurity survey, people are asked 18 questions about whether or not their family members have had problems taking sufficient amounts of food during the 12 months prior to the survey. Among the 18 questions, 8 questions are specifically related to children's food security. Based on the number of "yes" answers, children in each household are determined to be either food secure or food insecure (Gundersen \& Oliveira, 2001; Coleman-Jensen, Nord, \& Singh, 2013). Following the USDA guideline, our study considers a child to be in food insecure if the number of affirmative responses is larger than or equal to three (i.e., food insecurity without hunger). Another way to measure the food insecurity is the Rasch scale. The Rasch scale is generated still based on the number of affirmative responses to the food insecurity questions. However, unlike the binary variable (whether the child suffers from food insecurity or not), it provides a continuous scale to measure the severity of food insecurity. An increase in the Rasch scale indicates an increase in the severity of food insecurity, and as a household experiences less severe food insecurity, the value of the Rasch scale decreases. Generation of the Rasch scale is based on the item response theory in mathematics and psychometrics (Rasch, 1960/1980), and many studies have used the Rasch scale to define the food insecurity (e.g., Dunifon \&Kowaleski-Jones, 2003; Wilde \& Nord, 2005; Yen, Andrews, Chen, \& Eastwood, 2008).

Table 1 presents descriptive statistics of major variables used for the binary dependent variable model (probit model) and the Rasch-scale dependent variable model (truncated regression model) for years, 2001, 2004, 2007, and 2010. The sample for the binary model includes both food secure and food insecure children, while the sample for the Rasch-scale model includes only food insecure children after dropping food secure children from the dataset. Mean values of both dependent variables: binary and Rasch-scale reveal increasing trends over all, indicating that households with children become more food insecure and their food insecurity becomes more severe during the sample period. In the same period of time, the proportion of households living with children that are in food insecurity ranges from $9.9 \%$ to $13.84 \%$. Mean values (proportions) of School, Preschool, Male, and Female only from children in food insecurity are close to those from the full sample that includes both food secure and insecure children. However, proportions of White from the food insecurity sample are definitely smaller than those from the full sample, while proportions of Black and Hispanic are larger in the food insecurity sample than in the full sample. These statistics indicate that non-Hispanic white children are less likely to fall into food insecurity compared to non-Hispanic black and Hispanic children. Percentages of children living with married couples are smaller in the Rasch-scale sample than in the full sample, but children living with single mother are significantly higher in the Rasch-scale sample. The difference suggests that children living in married couple households are less likely to face food insecurity problem than those living in single-mom households. Interestingly, percentages of children with single father are smaller in the food insecurity sample than in the full sample, which might reflect the income gap between single-mother and single-father households. Similar results are observed from income variables. Children living with low income households are more likely to be food insecure (e.g., children living in households with income/poverty less than 1.0 account for $19.84 \%$ from the full sample but $51.70 \%$ from the food insecurity sample in 2001), whereas children living with high income households are less likely to be food insecure (e.g., children living in households with income/poverty larger than 1.8 account for $62.98 \%$ from the full sample but $21.11 \%$ from the food insecurity sample in 2001). Children living in Northeast and Midwest tend to be more food secure (e.g., percentage of children in Northeast and Midwest are 15.16\% and 21.56\%, respectively, from the full sample but $11.95 \%$ and $19.65 \%$, respectively, from the food insecurity sample in 2010), while children living in the South and the West tend to be more food insecure than other regions (e.g., percentage of children living in South and West are 38.47\% and 24.81\%, respectively, from the full sample but $41.93 \%$ and $26.09 \%$, respectively, from the food insecurity sample in 2010 ). Statistics in Table 1 also show that children's food security status improves with the reference person's education level (e.g., percentages of children living with the reference person who has less than high school education are $16.59 \%$ and $27.05 \%$ from full and food insecurity samples, respectively, but percentages of children living with the reference person who has graduate degree are 5.65\% and $1.39 \%$ from the respective samples in 2010). Not surprisingly, lower percentages of food insecure children are observed from children living with employed reference persons (e.g., 64.59\% from the full sample vs. $54.86 \%$ from the food insecurity sample in 2010). Mean values of all indicator variables, NSLP, SNAP, and WIC, suggest that children living with households participating in these food programs are more likely to be food insecure than children living with non-participating households (e.g., $28.18 \%$, 54.52\%, and $17.51 \%$ from the full sample vs. $45.40 \%$. $74.13 \%$, and 
23.86\% from the food insecure sample for SNAP, NSLP, and WIC, respectively, in 2007). The result strongly indicates the possibility of endogenous food program variables in specifying food insecurity models as stated in earlier sections.

Table 1. Descriptive Statistics of Variables Used for Binary and Rasch-Scale Models

\begin{tabular}{|c|c|c|c|c|c|c|c|c|}
\hline \multirow{2}{*}{ Variable } & \multicolumn{4}{|c|}{ Binary Model } & \multicolumn{4}{|c|}{ Rasch-Scale Model } \\
\hline & 2001 & 2004 & 2007 & 2010 & 2001 & 2004 & 2007 & 2010 \\
\hline Dependent & 0.0988 & 0.1333 & 0.1219 & 0.1384 & 5.5476 & 5.6323 & 5.8610 & 5.8221 \\
\hline Variable & $(0.1399)$ & $(0.1595)$ & $(0.1629)$ & $(0.1824)$ & $(0.8282)$ & $(0.8197)$ & $(0.9652)$ & $(1.0124)$ \\
\hline School & $\begin{array}{l}0.6694 \\
(0.2078)\end{array}$ & $\begin{array}{l}0.6629 \\
(0.2125)\end{array}$ & $\begin{array}{l}0.6514 \\
(0.2249)\end{array}$ & $\begin{array}{l}0.6483 \\
(0.2311)\end{array}$ & $\begin{array}{l}0.6895 \\
(0.2229)\end{array}$ & $\begin{array}{l}0.6964 \\
(0.2208)\end{array}$ & $\begin{array}{l}0.6800 \\
(0.2362)\end{array}$ & $\begin{array}{l}0.6936 \\
(0.2426)\end{array}$ \\
\hline Preschool & 0.3306 & 0.3371 & 0.3486 & 0.3517 & 0.3105 & 0.3036 & 0.3200 & 0.3064 \\
\hline Male & $\begin{array}{l}0.5142 \\
(0.2208)\end{array}$ & $\begin{array}{l}0.5111 \\
(0.2247)\end{array}$ & $\begin{array}{l}0.5111 \\
(0.2359)\end{array}$ & $\begin{array}{l}0.5115 \\
(0.2419)\end{array}$ & $\begin{array}{l}0.5195 \\
(0.2407)\end{array}$ & $\begin{array}{l}0.5190 \\
(0.2399)\end{array}$ & $\begin{array}{l}0.5159 \\
(0.2530)\end{array}$ & $\begin{array}{l}0.4981 \\
(0.2631)\end{array}$ \\
\hline Female & $\begin{array}{l}0.4858 \\
(0.2208)\end{array}$ & $\begin{array}{l}0.4889 \\
(0.2247)\end{array}$ & $\begin{array}{l}0.4889 \\
(0.2359)\end{array}$ & $\begin{array}{l}0.4885 \\
(0.2419)\end{array}$ & $\begin{array}{l}0.4805 \\
(0.2407)\end{array}$ & $\begin{array}{l}0.4810 \\
(0.2399)\end{array}$ & $\begin{array}{l}0.4841 \\
(0.2530)\end{array}$ & $\begin{array}{l}0.5019 \\
(0.2631)\end{array}$ \\
\hline White & $\begin{array}{l}0.6274 \\
(0.2136)\end{array}$ & $\begin{array}{l}0.5516 \\
(0.2236)\end{array}$ & $\begin{array}{l}0.5168 \\
(0.2359)\end{array}$ & $\begin{array}{l}0.4938 \\
(0.2420)\end{array}$ & $\begin{array}{l}0.4127 \\
(0.2372)\end{array}$ & $\begin{array}{l}0.3877 \\
(0.2339)\end{array}$ & $\begin{array}{l}0.3866 \\
(0.2466)\end{array}$ & $\begin{array}{l}0.3195 \\
(0.2454)\end{array}$ \\
\hline Black & $\begin{array}{l}0.1508 \\
(0.1581)\end{array}$ & $\begin{array}{l}0.1627 \\
(0.1660)\end{array}$ & $\begin{array}{l}0.1626 \\
(0.1742)\end{array}$ & $\begin{array}{l}0.1619 \\
(0.1783)\end{array}$ & $\begin{array}{l}0.2547 \\
(0.2099)\end{array}$ & $\begin{array}{l}0.2293 \\
(0.2018)\end{array}$ & $\begin{array}{l}0.2000 \\
(0.2025)\end{array}$ & $\begin{array}{l}0.2282 \\
(0.2208)\end{array}$ \\
\hline Hispanic & $\begin{array}{l}0.1656 \\
(0.1642)\end{array}$ & $\begin{array}{l}0.2051 \\
(0.1815)\end{array}$ & $\begin{array}{l}0.2403 \\
(0.2017)\end{array}$ & $\begin{array}{l}0.2528 \\
(0.2103)\end{array}$ & $\begin{array}{l}0.2813 \\
(0.2166)\end{array}$ & $\begin{array}{l}0.2906 \\
(0.218)\end{array}$ & $\begin{array}{l}0.3476 \\
(0.2411)\end{array}$ & $\begin{array}{l}0.3630 \\
(0.2531)\end{array}$ \\
\hline Other race & $\begin{array}{l}0.0562 \\
(0.1017)\end{array}$ & $\begin{array}{l}0.0806 \\
(0.1224)\end{array}$ & $\begin{array}{l}0.0804 \\
(0.1283)\end{array}$ & $\begin{array}{l}0.0915 \\
(0.1395)\end{array}$ & $\begin{array}{l}0.0513 \\
(0.1063)\end{array}$ & $\begin{array}{l}0.0924 \\
(0.1391)\end{array}$ & $\begin{array}{l}0.0657 \\
(0.1255)\end{array}$ & $\begin{array}{l}0.0892 \\
(0.1500)\end{array}$ \\
\hline Married couple & $\begin{array}{l}0.6898 \\
(0.2044)\end{array}$ & $\begin{array}{l}0.6445 \\
(0.2152)\end{array}$ & $\begin{array}{l}0.6154 \\
(0.2296)\end{array}$ & $\begin{array}{l}0.5867 \\
(0.2383)\end{array}$ & $\begin{array}{l}0.5138 \\
(0.2408)\end{array}$ & $\begin{array}{l}0.5060 \\
(0.2400)\end{array}$ & $\begin{array}{l}0.4815 \\
(0.2530)\end{array}$ & $\begin{array}{l}0.4705 \\
(0.2627)\end{array}$ \\
\hline Single mother & $\begin{array}{l}0.2435 \\
(0.1896)\end{array}$ & $\begin{array}{l}0.2816 \\
(0.2022)\end{array}$ & $\begin{array}{l}0.3059 \\
(0.2175)\end{array}$ & $\begin{array}{l}0.3195 \\
(0.2257)\end{array}$ & $\begin{array}{l}0.4295 \\
(0.2384)\end{array}$ & $\begin{array}{l}0.4322 \\
(0.2378)\end{array}$ & $\begin{array}{l}0.4542 \\
(0.2521)\end{array}$ & $\begin{array}{l}0.4492 \\
(0.2618)\end{array}$ \\
\hline Single father & $\begin{array}{l}0.0526 \\
(0.0987)\end{array}$ & $\begin{array}{l}0.0611 \\
(0.1077)\end{array}$ & $\begin{array}{l}0.0641 \\
(0.1156)\end{array}$ & $\begin{array}{l}0.0758 \\
(0.1281)\end{array}$ & $\begin{array}{l}0.0347 \\
(0.0882)\end{array}$ & $\begin{array}{l}0.0466 \\
(0.1012)\end{array}$ & $\begin{array}{l}0.0504 \\
(0.1108)\end{array}$ & $\begin{array}{l}0.0565 \\
(0.1215)\end{array}$ \\
\hline Other household & $\begin{array}{l}0.0140 \\
(0.0519)\end{array}$ & $\begin{array}{l}0.0127 \\
(0.0503)\end{array}$ & $\begin{array}{l}0.0146 \\
(0.0565)\end{array}$ & $\begin{array}{l}0.0181 \\
(0.0645)\end{array}$ & $\begin{array}{l}0.0220 \\
(0.0707)\end{array}$ & $\begin{array}{l}0.0151 \\
(0.0586)\end{array}$ & $\begin{array}{l}0.0139 \\
(0.0593)\end{array}$ & $\begin{array}{l}0.0238 \\
(0.0803)\end{array}$ \\
\hline Income1 & $\begin{array}{l}0.1984 \\
(0.1762)\end{array}$ & $\begin{array}{l}0.2359 \\
(0.1909)\end{array}$ & $\begin{array}{l}0.2428 \\
(0.2024)\end{array}$ & $\begin{array}{l}0.3068 \\
(0.2232)\end{array}$ & $\begin{array}{l}0.5170 \\
(0.2407)\end{array}$ & $\begin{array}{l}0.4926 \\
(0.2400)\end{array}$ & $\begin{array}{l}0.5096 \\
(0.2531)\end{array}$ & $\begin{array}{l}0.5120 \\
(0.2630)\end{array}$ \\
\hline Income 2 & $\begin{array}{l}0.0643 \\
(0.1083)\end{array}$ & $\begin{array}{l}0.0816 \\
(0.1231)\end{array}$ & $\begin{array}{l}0.0790 \\
(0.1273)\end{array}$ & $\begin{array}{l}0.1169 \\
(0.1555)\end{array}$ & $\begin{array}{l}0.1223 \\
(0.1578)\end{array}$ & $\begin{array}{l}0.1234 \\
(0.1579)\end{array}$ & $\begin{array}{l}0.1193 \\
(0.1641)\end{array}$ & $\begin{array}{l}0.1555 \\
(0.1907)\end{array}$ \\
\hline Income 3 & $\begin{array}{l}0.1075 \\
(0.1369)\end{array}$ & $\begin{array}{l}0.1465 \\
(0.159)\end{array}$ & $\begin{array}{l}0.1652 \\
(0.1753)\end{array}$ & $\begin{array}{l}0.1312 \\
(0.1634)\end{array}$ & $\begin{array}{l}0.1495 \\
(0.1718)\end{array}$ & $\begin{array}{l}0.1710 \\
(0.1808)\end{array}$ & $\begin{array}{l}0.1713 \\
(0.1908)\end{array}$ & $\begin{array}{l}0.1510 \\
(0.1884)\end{array}$ \\
\hline Income4 & $\begin{array}{l}0.6298 \\
(0.2133)\end{array}$ & $\begin{array}{l}0.5360 \\
(0.2242)\end{array}$ & $\begin{array}{l}0.5130 \\
(0.2359)\end{array}$ & $\begin{array}{l}0.4451 \\
(0.2405)\end{array}$ & $\begin{array}{l}0.2111 \\
(0.1966)\end{array}$ & $\begin{array}{l}0.2131 \\
(0.1966)\end{array}$ & $\begin{array}{l}0.1998 \\
(0.2024)\end{array}$ & $\begin{array}{l}0.1814 \\
(0.2028)\end{array}$ \\
\hline Metropolitan & $\begin{array}{l}0.8176 \\
(0.1706)\end{array}$ & $\begin{array}{l}0.8027 \\
(0.1789)\end{array}$ & $\begin{array}{l}0.8177 \\
(0.1822)\end{array}$ & $\begin{array}{l}0.8264 \\
(0.1833)\end{array}$ & $\begin{array}{l}0.7991 \\
(0.1930)\end{array}$ & $\begin{array}{l}0.7992 \\
(0.1923)\end{array}$ & $\begin{array}{l}0.8135 \\
(0.1972)\end{array}$ & $\begin{array}{l}0.8479 \\
(0.1890)\end{array}$ \\
\hline Non Metropolitan & $\begin{array}{l}0.1797 \\
(0.1696)\end{array}$ & $\begin{array}{l}0.1898 \\
(0.1763)\end{array}$ & $\begin{array}{l}0.1718 \\
(0.1781)\end{array}$ & $\begin{array}{l}0.1641 \\
(0.1792)\end{array}$ & $\begin{array}{l}0.1998 \\
(0.1926)\end{array}$ & $\begin{array}{l}0.1931 \\
(0.1895)\end{array}$ & $\begin{array}{l}0.1773 \\
(0.1934)\end{array}$ & $\begin{array}{l}0.1413 \\
(0.1833)\end{array}$ \\
\hline Northeast & $\begin{array}{l}0.1733 \\
(0.1672)\end{array}$ & $\begin{array}{l}0.1524 \\
(0.1616)\end{array}$ & $\begin{array}{l}0.1525 \\
(0.1697)\end{array}$ & $\begin{array}{l}0.1516 \\
(0.1736)\end{array}$ & $\begin{array}{l}0.1195 \\
(0.1562)\end{array}$ & $\begin{array}{l}0.1368 \\
(0.1650)\end{array}$ & $\begin{array}{l}0.1382 \\
(0.1747)\end{array}$ & $\begin{array}{l}0.1233 \\
(0.1730)\end{array}$ \\
\hline Midwest & $\begin{array}{l}0.2377 \\
(0.1881)\end{array}$ & $\begin{array}{l}0.2273 \\
(0.1884)\end{array}$ & $\begin{array}{l}0.2201 \\
(0.1956)\end{array}$ & $\begin{array}{l}0.2156 \\
(0.1990)\end{array}$ & $\begin{array}{l}0.1997 \\
(0.1926)\end{array}$ & $\begin{array}{l}0.2157 \\
(0.1975)\end{array}$ & $\begin{array}{l}0.2217 \\
(0.2103)\end{array}$ & $\begin{array}{l}0.1965 \\
(0.2091)\end{array}$ \\
\hline South & $\begin{array}{l}0.3462 \\
(0.2102)\end{array}$ & $\begin{array}{l}0.3692 \\
(0.217)\end{array}$ & $\begin{array}{l}0.3820 \\
(0.2293)\end{array}$ & $\begin{array}{l}0.3847 \\
(0.2355)\end{array}$ & $\begin{array}{l}0.3783 \\
(0.2336)\end{array}$ & $\begin{array}{l}0.3576 \\
(0.2301)\end{array}$ & $\begin{array}{l}0.4046 \\
(0.2485)\end{array}$ & $\begin{array}{l}0.4193 \\
(0.2597)\end{array}$ \\
\hline West & $\begin{array}{l}0.2429 \\
(0.1895)\end{array}$ & $\begin{array}{l}0.2511 \\
(0.1950)\end{array}$ & $\begin{array}{l}0.2454 \\
(0.2031)\end{array}$ & $\begin{array}{l}0.2481 \\
(0.2090)\end{array}$ & $\begin{array}{l}0.3025 \\
(0.2213)\end{array}$ & $\begin{array}{l}0.2899 \\
(0.2178)\end{array}$ & $\begin{array}{l}0.2356 \\
(0.2149)\end{array}$ & $\begin{array}{l}0.2609 \\
(0.2311)\end{array}$ \\
\hline $\begin{array}{l}\text { Less than high } \\
\text { school }\end{array}$ & 0.1457 & 0.1678 & 0.1680 & 0.1659 & 0.2973 & 0.2760 & 0.2995 & 0.2705 \\
\hline & $(0.1559)$ & $(0.1680)$ & $(0.1765)$ & $(0.1800)$ & $(0.2202)$ & $(0.2146)$ & $(0.2319)$ & $(0.2338)$ \\
\hline Highschool & $\begin{array}{l}0.3058 \\
(0.2036)\end{array}$ & $\begin{array}{l}0.3314 \\
(0.2116)\end{array}$ & $\begin{array}{l}0.3314 \\
(0.2222)\end{array}$ & $\begin{array}{l}0.3154 \\
(0.2249)\end{array}$ & $\begin{array}{l}0.3726 \\
(0.2329)\end{array}$ & $\begin{array}{l}0.3773 \\
(0.2327)\end{array}$ & $\begin{array}{l}0.3579 \\
(0.2427)\end{array}$ & $\begin{array}{l}0.3347 \\
(0.2483)\end{array}$ \\
\hline Somecollege & $\begin{array}{l}0.2887 \\
(0.2002)\end{array}$ & $\begin{array}{l}0.3031 \\
(0.2066)\end{array}$ & $\begin{array}{l}0.3045 \\
(0.2172)\end{array}$ & $\begin{array}{l}0.3162 \\
(0.2250)\end{array}$ & $\begin{array}{l}0.2750 \\
(0.2151)\end{array}$ & $\begin{array}{l}0.2788 \\
(0.2153)\end{array}$ & $\begin{array}{l}0.2729 \\
(0.2256)\end{array}$ & $\begin{array}{l}0.3025 \\
(0.2417)\end{array}$ \\
\hline Bachelor & $\begin{array}{l}0.1686 \\
(0.1654)\end{array}$ & $\begin{array}{l}0.1419 \\
(0.1569)\end{array}$ & $\begin{array}{l}0.1418 \\
(0.1647)\end{array}$ & $\begin{array}{l}0.1460 \\
(0.1709)\end{array}$ & $\begin{array}{l}0.0417 \\
(0.0962)\end{array}$ & $\begin{array}{l}0.0522 \\
(0.1067)\end{array}$ & $\begin{array}{l}0.0519 \\
(0.1123)\end{array}$ & $\begin{array}{l}0.0784 \\
(0.1414)\end{array}$ \\
\hline Graduate & $\begin{array}{l}0.0912 \\
(0.1272)\end{array}$ & $\begin{array}{l}0.0558 \\
(0.1032)\end{array}$ & $\begin{array}{l}0.0544 \\
(0.1070)\end{array}$ & $\begin{array}{l}0.0565 \\
(0.1117)\end{array}$ & $\begin{array}{l}0.0134 \\
(0.0554)\end{array}$ & $\begin{array}{l}0.0157 \\
(0.0597)\end{array}$ & $\begin{array}{l}0.0178 \\
(0.067)\end{array}$ & $\begin{array}{l}0.0139 \\
(0.0617)\end{array}$ \\
\hline Employed & $\begin{array}{l}0.7641 \\
(0.1876)\end{array}$ & $\begin{array}{l}0.7267 \\
(0.2004)\end{array}$ & $\begin{array}{l}0.7072 \\
(0.2148)\end{array}$ & $\begin{array}{l}0.6459 \\
(0.2314)\end{array}$ & $\begin{array}{l}0.6335 \\
(0.2321)\end{array}$ & $\begin{array}{l}0.6194 \\
(0.2331)\end{array}$ & $\begin{array}{l}0.5895 \\
(0.2491)\end{array}$ & $\begin{array}{l}0.5486 \\
(0.2619)\end{array}$ \\
\hline SNAP & $\begin{array}{l}0.2207 \\
(0.1981)\end{array}$ & $\begin{array}{l}0.2661 \\
(0.2118)\end{array}$ & $\begin{array}{l}0.2818 \\
(0.2274)\end{array}$ & $\begin{array}{l}0.3687 \\
(0.2509)\end{array}$ & $\begin{array}{l}0.3409 \\
(0.2283)\end{array}$ & $\begin{array}{l}0.3948 \\
(0.2347)\end{array}$ & $\begin{array}{l}0.4540 \\
(0.2521)\end{array}$ & $\begin{array}{l}0.4941 \\
(0.2631)\end{array}$ \\
\hline NSLP & $\begin{array}{l}0.5221 \\
(0.2386)\end{array}$ & $\begin{array}{l}0.5493 \\
(0.2385)\end{array}$ & $\begin{array}{l}0.5452 \\
(0.2517)\end{array}$ & $\begin{array}{l}0.5930 \\
(0.2554)\end{array}$ & $\begin{array}{l}0.6746 \\
(0.2257)\end{array}$ & $\begin{array}{l}0.7192 \\
(0.2158)\end{array}$ & $\begin{array}{l}0.7413 \\
(0.2217)\end{array}$ & $\begin{array}{l}0.7593 \\
(0.2250)\end{array}$ \\
\hline WIC & $\begin{array}{l}0.1837 \\
(0.1825)\end{array}$ & $\begin{array}{l}0.1870 \\
(0.1869)\end{array}$ & $\begin{array}{l}0.1751 \\
(0.1921)\end{array}$ & $\begin{array}{l}0.2055 \\
(0.2101)\end{array}$ & $\begin{array}{l}0.2328 \\
(0.2036)\end{array}$ & $\begin{array}{l}0.2430 \\
(0.2059)\end{array}$ & $\begin{array}{l}0.2386 \\
(0.2158)\end{array}$ & $\begin{array}{l}0.2551 \\
(0.2294)\end{array}$ \\
\hline
\end{tabular}


Numbers in parentheses are standard deviations.

\section{Empirical Results}

Estimation results from probit and truncated regression models, (3) and (4), are reported in Table 2.

Table 2. Estimates from Probit and Truncated Regressions

\begin{tabular}{|c|c|c|c|c|c|c|c|c|}
\hline \multirow{2}{*}{ Variable } & \multicolumn{4}{|c|}{ Binary Model } & \multicolumn{4}{|c|}{ Rasch-Scale Model } \\
\hline & 2001 & 2004 & 2007 & 2010 & 2001 & 2004 & 2007 & 2010 \\
\hline \multirow[t]{2}{*}{ Intercept } & $-1.9842^{\mathrm{A}}$ & $-1.8132^{\mathrm{A}}$ & $-1.6661^{\mathrm{A}}$ & $-1.9079^{\mathrm{A}}$ & $4.6866^{\mathrm{A}}$ & $4.7770^{\mathrm{A}}$ & $5.1066^{\mathrm{A}}$ & $5.2565^{\mathrm{A}}$ \\
\hline & $(0.0573)$ & $(0.0547)$ & $(0.0688)$ & $(0.0601)$ & $(0.1204)$ & $(0.1181)$ & $(0.1763)$ & $(0.1425)$ \\
\hline \multirow[t]{2}{*}{ Schoolage } & $0.0880^{\mathrm{A}}$ & $0.0843^{\mathrm{A}}$ & 0.0226 & $0.0920^{\mathrm{A}}$ & $0.2585^{\mathrm{A}}$ & $0.2679^{A}$ & $0.2341^{\mathrm{A}}$ & $0.1337^{\mathrm{B}}$ \\
\hline & $(0.0254)$ & $(0.0244)$ & $(0.0305)$ & $(0.0252)$ & $(0.0514)$ & $(0.0503)$ & $(0.0745)$ & $(0.0586)$ \\
\hline \multirow[t]{2}{*}{ Female } & -0.0267 & -0.0167 & -0.0231 & 0.0089 & 0.0521 & -0.0707 & 0.0518 & $0.0972^{\mathrm{C}}$ \\
\hline & $(0.0222)$ & $(0.0212)$ & $(0.0270)$ & $(0.0221)$ & $(0.0446)$ & $(0.0435)$ & $(0.0647)$ & $(0.0502)$ \\
\hline \multirow[t]{2}{*}{ Black } & $0.2051^{\mathrm{A}^{\prime}}$ & $0.1386^{\mathrm{A}}$ & -0.0233 & $0.2234^{A}$ & $0.2860^{\mathrm{A}}$ & $0.1936^{A}$ & $0.2094^{\mathrm{B}}$ & $0.3037^{A}$ \\
\hline & $(0.0311)$ & $(0.0309)$ & $(0.0406)$ & $(0.0328)$ & $(0.0602)$ & $(0.0617)$ & $(0.0949)$ & $(0.0728)$ \\
\hline \multirow[t]{2}{*}{ Hispanic } & $0.1485^{\mathrm{A}}$ & $0.1910^{\mathrm{A}}$ & $0.0787^{\mathrm{B}}$ & $0.2137^{A}$ & $0.4186^{\mathrm{A}}$ & $0.3344^{\mathrm{A}}$ & $0.2757^{\mathrm{A}}$ & $0.2882^{A}$ \\
\hline & $(0.0320)$ & $(0.0305)$ & $(0.0380)$ & $(0.0304)$ & $(0.0644)$ & $(0.0635)$ & $(0.0911)$ & $(0.0702)$ \\
\hline \multirow[t]{2}{*}{ Other race } & $0.2250^{\mathrm{A}}$ & $0.1693^{\mathrm{A}}$ & -0.0560 & $0.1521^{\mathrm{A}}$ & $0.6702^{\mathrm{A}}$ & $0.4800^{\mathrm{A}}$ & -0.1271 & $0.3047^{\mathrm{A}}$ \\
\hline & $(0.0466)$ & $(0.0396)$ & $(0.0541)$ & $(0.0402)$ & $(0.1023)$ & $(0.0824)$ & $(0.1327)$ & $(0.0939)$ \\
\hline \multirow[t]{2}{*}{ Single mother } & $0.1954^{\mathrm{A}}$ & $0.1967^{\mathrm{A}}$ & $0.2198^{\mathrm{A}}$ & $0.1854^{\mathrm{A}}$ & $0.1292^{\mathrm{B}}$ & 0.0722 & $0.2710^{\mathrm{A}}$ & 0.0859 \\
\hline & $(0.0263)$ & $(0.0250)$ & $(0.0320)$ & $(0.0259)$ & $(0.0513)$ & $(0.0491)$ & $(0.0745)$ & $(0.0574)$ \\
\hline \multirow[t]{2}{*}{ Single father } & 0.0472 & $0.1907^{\mathrm{A}}$ & $0.2079^{A}$ & $0.1286^{\mathrm{A}}$ & 0.1075 & $0.2752^{A}$ & $0.2423^{C}$ & 0.1070 \\
\hline & $(0.0474)$ & $(0.0429)$ & $(0.0548)$ & $(0.0437)$ & $(0.1005)$ & $(0.0877)$ & $(0.1284)$ & $(0.0989)$ \\
\hline \multirow[t]{2}{*}{ Other household } & $0.2995^{\mathrm{A}}$ & 0.0256 & -0.0019 & $0.2489^{A}$ & $0.3330^{\mathrm{B}}$ & -0.0100 & -0.2666 & -0.0536 \\
\hline & $(0.0790)$ & $(0.0913)$ & $(0.1158)$ & $(0.0769)$ & $(0.1599)$ & $(0.1892)$ & $(0.2770)$ & $(0.1710)$ \\
\hline \multirow[t]{2}{*}{ Income1 } & $0.5107^{\mathrm{A}}$ & $0.3918^{\mathrm{A}}$ & $0.3200^{\mathrm{A}}$ & $0.3945^{\mathrm{A}}$ & $0.4109^{\mathrm{A}}$ & $0.4141^{\mathrm{A}}$ & 0.0593 & $0.2654^{\mathrm{A}}$ \\
\hline & $(0.0331)$ & $(0.0319)$ & $(0.0421)$ & $(0.0346)$ & $(0.0731)$ & $(0.0697)$ & $(0.1077)$ & $(0.0796)$ \\
\hline \multirow[t]{2}{*}{ Income2 } & $0.3970^{\mathrm{A}}$ & $0.3836^{\mathrm{A}}$ & $0.2989^{\mathrm{A}}$ & $0.3006^{\mathrm{A}}$ & -0.0060 & $0.3214^{\mathrm{A}}$ & -0.1389 & -0.0367 \\
\hline & $(0.0420)$ & $(0.0396)$ & $(0.0529)$ & $(0.0400)$ & $(0.0868)$ & $(0.0843)$ & $(0.1249)$ & $(0.0914)$ \\
\hline \multirow[t]{2}{*}{ Income3 } & $0.2891^{A}$ & $0.2048^{\mathrm{A}}$ & $0.1195^{\mathrm{A}}$ & $0.3899^{A}$ & $0.1462^{\mathrm{C}}$ & $0.1397^{\mathrm{C}}$ & $-0.2525^{\mathrm{B}}$ & 0.0886 \\
\hline & $(0.0370)$ & $(0.0345)$ & $(0.0438)$ & $(0.0373)$ & $(0.0815)$ & $(0.0765)$ & $(0.1126)$ & $(0.0878)$ \\
\hline \multirow[t]{2}{*}{ Metropolitan } & $0.0838^{\mathrm{A}}$ & $0.0774^{\mathrm{A}}$ & $0.1065^{\mathrm{A}}$ & $0.0792^{\mathrm{B}}$ & $0.2104^{A}$ & $0.2404^{A}$ & $0.3753^{A}$ & 0.0209 \\
\hline & $(0.0296)$ & $(0.0295)$ & $(0.0374)$ & $(0.0319)$ & $(0.0581)$ & $(0.0589)$ & $(0.0874)$ & $(0.0735)$ \\
\hline \multirow[t]{2}{*}{ Midwest } & $0.0985^{\mathrm{B}}$ & $0.0624^{\mathrm{C}}$ & -0.0664 & -0.0252 & -0.0764 & -0.0694 & -0.1084 & $-0.2445^{\mathrm{A}}$ \\
\hline & $(0.0397)$ & $(0.0365)$ & $(0.0456)$ & $(0.0388)$ & $(0.0808)$ & $(0.0767)$ & $(0.1128)$ & $(0.0894)$ \\
\hline \multirow[t]{2}{*}{ South } & $0.2447^{\mathrm{A}}$ & 0.0422 & -0.0572 & 0.0343 & 0.0027 & -0.0519 & -0.0901 & $-0.1504^{\mathrm{C}}$ \\
\hline & $(0.0354)$ & $(0.0328)$ & $(0.0406)$ & $(0.0341)$ & $(0.0725)$ & $(0.0700)$ & $(0.1006)$ & $(0.0787)$ \\
\hline \multirow[t]{2}{*}{ West } & $0.3355^{\mathrm{A}}$ & $0.0824^{\mathrm{B}}$ & -0.0684 & 0.0565 & 0.1161 & -0.0638 & 0.0381 & 0.0758 \\
\hline & $(0.0377)$ & $(0.0355)$ & $(0.0447)$ & $(0.0369)$ & $(0.0776)$ & $(0.0751)$ & $(0.1112)$ & $(0.0858)$ \\
\hline \multirow[t]{2}{*}{ High school } & $-0.0909^{\mathrm{A}}$ & $-0.0608^{\mathrm{B}}$ & $-0.2041^{\mathrm{A}}$ & $-0.1522^{\mathrm{A}}$ & 0.0696 & 0.0622 & $-0.1764^{\mathrm{B}}$ & $-0.2263^{\mathrm{A}}$ \\
\hline & $(0.0301)$ & $(0.0296)$ & $(0.0376)$ & $(0.0326)$ & $(0.0579)$ & $(0.0582)$ & $(0.0861)$ & $(0.0709)$ \\
\hline Some college & $-0.1410^{\mathrm{A}}$ & $-0.0735^{\mathrm{B}}$ & $-0.2321^{\mathrm{A}}$ & $-0.0816^{\mathrm{B}}$ & -0.0641 & 0.0473 & $-0.3950^{\mathrm{A}}$ & -0.0779 \\
\hline & $(0.0329)$ & $(0.0317)$ & $(0.0408)$ & $(0.0340)$ & $(0.0642)$ & $(0.0635)$ & $(0.0953)$ & $(0.0755)$ \\
\hline Bachelor & $-0.6067^{\mathrm{A}}$ & $-0.4709^{\mathrm{A}}$ & $-0.4732^{\mathrm{A}}$ & $-0.1949^{\mathrm{A}}$ & $-0.2541^{\mathrm{B}}$ & -0.1463 & $-0.2498^{\mathrm{C}}$ & 0.0076 \\
\hline & $(0.0534)$ & $(0.0479)$ & $(0.0552)$ & $(0.0442)$ & $(0.1187)$ & $(0.1069)$ & $(0.1466)$ & $(0.1051)$ \\
\hline Graduate & $-0.5576^{\mathrm{A}}$ & $-0.4817^{\mathrm{A}}$ & $-0.6852^{A}$ & $-0.3582^{A}$ & $0.3483^{C}$ & $0.3750^{\mathrm{B}}$ & -0.0139 & 0.0773 \\
\hline & $(0.0691)$ & $(0.0629)$ & $(0.0821)$ & $(0.0618)$ & $(0.1855)$ & $(0.1635)$ & $(0.2655)$ & $(0.1780)$ \\
\hline Employed & $-0.1188^{\mathrm{A}}$ & $-0.1218^{\mathrm{A}}$ & -0.0010 & $-0.0592^{\mathrm{B}}$ & $-0.1614^{\mathrm{A}}$ & $-0.1220^{\mathrm{A}}$ & -0.0443 & $-0.1480^{\mathrm{A}}$ \\
\hline & $(0.0244)$ & $(0.0234)$ & $(0.0299)$ & $(0.0241)$ & $(0.0489)$ & $(0.0470)$ & $(0.0705)$ & $(0.0539)$ \\
\hline SNAP & $0.2335^{\mathrm{A}}$ & $0.2337^{\mathrm{A}}$ & $0.3158^{\mathrm{A}}$ & $0.2399^{\mathrm{A}}$ & $0.1023^{\mathrm{C}}$ & 0.0520 & $0.3300^{\mathrm{A}}$ & $0.1312^{\mathrm{B}}$ \\
\hline & $(0.0322)$ & $(0.0303)$ & $(0.0385)$ & $(0.0292)$ & $(0.0575)$ & $(0.0542)$ & $(0.0812)$ & $(0.0600)$ \\
\hline NSLP & $0.4775^{\mathrm{A}}$ & $0.6181^{\mathrm{A}}$ & $0.6337^{\mathrm{A}}$ & $0.5334^{\mathrm{A}}$ & $0.1199^{\mathrm{B}}$ & $0.1994^{\mathrm{A}}$ & $0.2605^{\mathrm{A}}$ & $0.2364^{\mathrm{A}}$ \\
\hline & $(0.0272)$ & $(0.0266)$ & $(0.0336)$ & $(0.0270)$ & $(0.0511)$ & $(0.0513)$ & $(0.0753)$ & $(0.0586)$ \\
\hline WIC & $0.1125^{\mathrm{A}}$ & 0.0157 & 0.0340 & 0.0467 & $-0.1005^{\mathrm{C}}$ & $-0.1311^{B}$ & -0.1108 & 0.0816 \\
\hline & $(0.0333)$ & $(0.0320)$ & $(0.0413)$ & $(0.0322)$ & $(0.0599)$ & $(0.0585)$ & $(0.0876)$ & $(0.0673)$ \\
\hline
\end{tabular}

Statistical significance is noted by ${ }^{\mathrm{A}}$, ${ }^{\mathrm{B}}$, and ${ }^{\mathrm{C}}$ at the $1 \%, 5 \%$, and $10 \%$ levels, respectively.

Numbers in parentheses are standard errors.

The binary model estimated with the probit procedure allows one to examine the impact of explanatory variables (representing children's demographics and living environments) on the probability of children falling into food insecurity. Estimates of Schoolage are significant at the 1\% level for all years except 2007. The positive sign of Schoolage coefficient indicates that school-age children are more likely to be food insecure than preschool-age children. 
The status of children's food insecurity is not affected by gender for all years but is significantly affected by race and family structure. Overall, black, Hispanic, and other race tend to be more likely to fall into food insecurity than the reference group, white, and similarly children living with single mother and father are more likely to be in food insecurity than ones living with married couple. Estimates of income variables (Income1, Income2, and Income3) clearly show that children living with low income households are highly likely to fall into food insecurity compared to those living with higher income households (Income4). Estimates of children living in the metropolitan area are all positive and statistically significant at least at the $5 \%$ level for all four years, which indicates those living in the metropolitan area are more likely to be food insecure compared to ones living in non-metropolitan area. Reference person's education level and employment status also look important factors determining children's food security status. Overall, children living with more educated and employed reference persons are less likely to fall into food insecurity compared to those living with less educated and unemployed reference persons. Estimates of dummy variables representing the participation of food programs, SNAP, NSLP, and WIC, indicate that children who receive food assistance are more prone to be food insecure. As discussed earlier, such results are apparently misleading probably due to the endogeneity problem of the food program variables, which will be further discussed with results in Table 3 after controlling for the endogeneity problem.

The Rasch-scale model is estimated with the truncated regression because the data is limited only to children who are in food insecurity, and results are reported in the right-hand side of Table 2. Overall, results are similar to those from the probit model, except that the results from the Rasch-scale model should be interpreted as impacts of independent variables on the severity of children's food insecurity. School-age children tend to experience more severe food insecurity than preschool-age children, and black, Hispanic, and other-race children also tend to be more severely food insecure than non-Hispanic white children. The extent of food insecurity is more severe from children living with single mother and single father than those with married couple. As expected, children living with lower income households (Income1, Income2, and Income3) have more severe food insecurity than those with higher income households (Income4). Children living in metropolitan area show more severely food insecure than those living in non-metropolitan area. Estimates of reference person's education and employment variables show that children's food insecurity status improves with reference person's education and employment. As with the results from the binary model, coefficients of SNAP, NSLP, and WIC are positive and mostly statistically significant except WIC in 2001, 2004, and 2007. Results from Table 2 are mostly consistent with findings from descriptive statistics reported in Table 1.

The probit and truncated equations are re-estimated with the simultaneous equation procedure to address the endogeneity problem of food program variables following (5) - (7), and results are reported in Table 3. 
Table 3. Estimates from Probit and Truncated Regressions with Simultaneous Equation Procedure

\begin{tabular}{|c|c|c|c|c|c|c|c|c|}
\hline \multirow{2}{*}{ Variable } & \multicolumn{4}{|c|}{ Binary Model } & \multicolumn{4}{|c|}{ Rasch-Scale Model } \\
\hline & 2001 & 2004 & 2007 & 2010 & 2001 & 2004 & 2007 & 2010 \\
\hline \multirow[t]{2}{*}{ Intercept } & $-1.7463^{\mathrm{A}}$ & $-1.2181^{\mathrm{A}}$ & $-0.9345^{\mathrm{A}}$ & $-1.8071^{\mathrm{A}}$ & $5.8997^{\mathrm{A}}$ & $4.7230^{\mathrm{A}}$ & $7.9599^{\mathrm{A}}$ & $5.5351^{\mathrm{A}}$ \\
\hline & $(0.1380)$ & $(0.1711)$ & $(0.0763)$ & $(0.1673)$ & $(0.3095)$ & $(0.4053)$ & $(0.4506)$ & $(0.2765)$ \\
\hline \multirow[t]{2}{*}{ Schoolage } & 0.1330 & $-0.3154^{\mathrm{B}}$ & -0.1010 & -0.0413 & $0.4116^{\mathrm{A}}$ & -0.3561 & 0.2805 & -0.1569 \\
\hline & $(0.1034)$ & $(0.1490)$ & $(0.0938)$ & $(0.1659)$ & $(0.1922)$ & $(0.2297)$ & $(0.2784)$ & $(0.2291)$ \\
\hline \multirow[t]{2}{*}{ Female } & 0.0289 & 0.0482 & $0.0534^{\mathrm{B}}$ & -0.0265 & $0.0928^{\mathrm{B}}$ & -0.0167 & -0.0222 & 0.0759 \\
\hline & $(0.0352)$ & $(0.0715)$ & $(0.0238)$ & $(0.0776)$ & $(0.0442)$ & $(0.0468)$ & $(0.0619)$ & $(0.0497)$ \\
\hline \multirow[t]{2}{*}{ Black } & $0.4445^{\mathrm{A}}$ & $0.8593^{\mathrm{A}}$ & $0.2806^{\mathrm{A}}$ & $0.7174^{\mathrm{B}}$ & $0.4857^{\mathrm{A}}$ & 0.0429 & $1.2544^{\mathrm{A}}$ & $0.2586^{\mathrm{C}}$ \\
\hline & $(0.1267)$ & $(0.1605)$ & $(0.0876)$ & $(0.3193)$ & $(0.0887)$ & $(0.1684)$ & $(0.1802)$ & $(0.1507)$ \\
\hline \multirow[t]{2}{*}{ Hispanic } & 0.0706 & 0.0441 & $0.4627^{\mathrm{A}}$ & $0.7684^{\mathrm{A}}$ & $0.6394^{\mathrm{A}}$ & 0.0984 & $0.7268^{A}$ & 0.1042 \\
\hline & $(0.1235)$ & $(0.1660)$ & $(0.1063)$ & $(0.2640)$ & $(0.1027)$ & $(0.1880)$ & $(0.1741)$ & $(0.1668)$ \\
\hline \multirow[t]{2}{*}{ Other race } & 0.1471 & $0.4302^{\mathrm{A}}$ & -0.0915 & 0.2816 & $0.6344^{\mathrm{A}}$ & $0.4483^{\mathrm{A}}$ & $0.5602^{\mathrm{A}}$ & $0.2570^{\mathrm{B}}$ \\
\hline & $(0.0921)$ & $(0.1497)$ & $(0.1242)$ & $(0.2368)$ & $(0.1225)$ & $(0.1739)$ & $(0.1656)$ & $(0.1083)$ \\
\hline \multirow[t]{2}{*}{ Single mother } & $-0.1465^{\mathrm{C}}$ & $0.3511^{\mathrm{B}}$ & $-0.2013^{\mathrm{A}}$ & 0.0713 & $0.4118^{\mathrm{A}}$ & 0.1278 & $1.2285^{\mathrm{A}}$ & $0.3496^{\mathrm{A}}$ \\
\hline & $(0.0783)$ & $(0.1576)$ & $(0.0780)$ & $(0.2093)$ & $(0.0969)$ & $(0.1275)$ & $(0.1639)$ & $(0.1052)$ \\
\hline \multirow[t]{2}{*}{ Single father } & $-0.8625^{\mathrm{A}}$ & $0.5693^{\mathrm{A}}$ & -0.0023 & $0.6252^{\mathrm{A}}$ & $0.1887^{\mathrm{C}}$ & $0.2407^{\mathrm{C}}$ & $0.3717^{\mathrm{A}}$ & 0.1617 \\
\hline & $(0.2877)$ & $(0.1394)$ & $(0.0572)$ & $(0.1726)$ & $(0.1087)$ & $(0.1244)$ & $(0.1407)$ & $(0.1051)$ \\
\hline \multirow[t]{2}{*}{ Other household } & 0.0871 & -1.3898 & -1.3392 & $1.1542^{\mathrm{A}}$ & $0.8331^{A}$ & 0.1545 & $-0.5614^{\mathrm{B}}$ & 0.0803 \\
\hline & $(0.2417)$ & $(1.2802)$ & $(0.8907)$ & $(0.2683)$ & $(0.2021)$ & $(0.2143)$ & $(0.2243)$ & $(0.1443)$ \\
\hline \multirow[t]{2}{*}{ Income1 } & $1.0497^{\mathrm{A}}$ & $2.0904^{\mathrm{A}}$ & $0.9269^{A}$ & 0.2366 & $1.6198^{A}$ & 0.1911 & $3.0213^{\mathrm{A}}$ & $0.6456^{\mathrm{C}}$ \\
\hline & $(0.3290)$ & $(0.5626)$ & $(0.2591)$ & $(0.4835)$ & $(0.3323)$ & $(0.3762)$ & $(0.4720)$ & $(0.3313)$ \\
\hline \multirow[t]{2}{*}{ Income2 } & $0.7018^{A}$ & 0.5867 & $0.8441^{\mathrm{A}}$ & -0.3900 & $0.6937^{A}$ & 0.0263 & $1.5382^{\mathrm{A}}$ & 0.0115 \\
\hline & $(0.2720)$ & $(0.4319)$ & $(0.2157)$ & $(0.4770)$ & $(0.1805)$ & $(0.2567)$ & $(0.3002)$ & $(0.2922)$ \\
\hline \multirow[t]{2}{*}{ Income3 } & 0.2112 & 0.0486 & $0.6115^{\mathrm{A}}$ & 0.1031 & $0.6017^{A}$ & -0.1769 & $0.8142^{\mathrm{A}}$ & 0.0080 \\
\hline & $(0.1986)$ & $(0.4004)$ & $(0.1655)$ & $(0.2823)$ & $(0.1347)$ & $(0.2156)$ & $(0.2331)$ & $(0.1852)$ \\
\hline \multirow[t]{2}{*}{ Metropolitan } & $0.1270^{\mathrm{B}}$ & -0.0889 & 0.0015 & $0.5695^{\mathrm{B}}$ & $0.1689^{A}$ & $0.3298^{A}$ & $0.2996^{\mathrm{B}}$ & -0.0178 \\
\hline & $(0.0614)$ & $(0.1169)$ & $(0.0625)$ & $(0.2390)$ & $(0.0522)$ & $(0.0823)$ & $(0.1227)$ & $(0.0778)$ \\
\hline \multirow[t]{2}{*}{ Midwest } & $0.6929^{\mathrm{A}}$ & $0.3465^{\mathrm{A}}$ & $0.1936^{\mathrm{B}}$ & $-0.2962^{\mathrm{C}}$ & -0.1244 & 0.0971 & 0.1826 & $-0.1849^{\mathrm{C}}$ \\
\hline & $(0.1692)$ & $(0.1292)$ & $(0.0847)$ & $(0.1526)$ & $(0.0789)$ & $(0.0967)$ & $(0.1182)$ & $(0.0988)$ \\
\hline \multirow[t]{2}{*}{ South } & $0.6950^{A^{\prime}}$ & 0.1342 & $0.1554^{\mathrm{B}}$ & $-0.6577^{\mathrm{A}}$ & $-0.1817^{B}$ & 0.0070 & 0.0424 & $-0.2447^{\mathrm{A}}$ \\
\hline & $(0.1679)$ & $(0.1136)$ & $(0.0771)$ & $(0.2258)$ & $(0.0843)$ & $(0.0810)$ & $(0.1026)$ & $(0.0837)$ \\
\hline \multirow[t]{2}{*}{ West } & $0.9807^{\mathrm{A}}$ & $0.3051^{\mathrm{A}}$ & $0.4266^{\mathrm{A}}$ & $-0.2189^{\mathrm{C}}$ & 0.1026 & -0.0528 & 0.1423 & 0.0411 \\
\hline & $(0.1756)$ & $(0.1159)$ & $(0.0877)$ & $(0.1320)$ & $(0.0853)$ & $(0.0924)$ & $(0.1298)$ & $(0.0905)$ \\
\hline \multirow[t]{2}{*}{ High school } & $-0.2183^{B}$ & $-0.4985^{\mathrm{A}}$ & -0.0258 & $-0.5215^{\mathrm{B}}$ & $-0.1313^{C}$ & -0.0158 & $-0.7898^{\mathrm{A}}$ & -0.1443 \\
\hline & $(0.0894)$ & $(0.1429)$ & $(0.0434)$ & $(0.2042)$ & $(0.0694)$ & $(0.0628)$ & $(0.1355)$ & $(0.1074)$ \\
\hline Some college & $-0.1898^{\mathrm{B}}$ & $-0.3503^{B}$ & $-0.2955^{\mathrm{A}}$ & $-0.4654^{\mathrm{B}}$ & $-0.3567^{A}$ & -0.0332 & $-1.0476^{\mathrm{A}}$ & -0.0385 \\
\hline & $(0.0858)$ & $(0.1470)$ & $(0.0962)$ & $(0.2256)$ & $(0.0957)$ & $(0.0806)$ & $(0.1567)$ & $(0.0974)$ \\
\hline Bachelor & $-0.5279^{A}$ & $-0.9471^{\mathrm{A}}$ & $-0.3638^{\mathrm{A}}$ & -0.1184 & $-0.8634^{\mathrm{A}}$ & -0.0925 & $-1.4021^{\mathrm{A}}$ & -0.0519 \\
\hline & $(0.1835)$ & $(0.2513)$ & $(0.1388)$ & $(0.1849)$ & $(0.1672)$ & $(0.1946)$ & $(0.2451)$ & $(0.2354)$ \\
\hline Graduate & $-0.4790^{\mathrm{B}}$ & $-0.5234^{\mathrm{B}}$ & -0.2430 & -2.0440 & $-0.5772^{\mathrm{B}}$ & $0.7827^{\mathrm{B}}$ & $-0.9079^{\mathrm{A}}$ & 0.1933 \\
\hline & $(0.1930)$ & $(0.2287)$ & $(0.1777)$ & $(1.6938)$ & $(0.2305)$ & $(0.3738)$ & $(0.3180)$ & $(0.3089)$ \\
\hline Employed & -0.1032 & $-4.2012^{\mathrm{A}}$ & $-0.2290^{\mathrm{A}}$ & -0.0895 & $-0.4687^{\mathrm{A}}$ & -0.1590 & $-0.7651^{\mathrm{A}}$ & $-0.3491^{\mathrm{A}}$ \\
\hline & $(0.0646)$ & $(1.5516)$ & $(0.0588)$ & $(0.1247)$ & $(0.1081)$ & $(0.1064)$ & $(0.1274)$ & $(0.0872)$ \\
\hline SNAP & -0.1186 & $-3.5434^{\mathrm{A}}$ & $0.5627^{\mathrm{B}}$ & $-1.6995^{\mathrm{C}}$ & $-0.8109^{C}$ & -0.7383 & $-4.2618^{\mathrm{A}}$ & $-1.7197^{\mathrm{A}}$ \\
\hline & $(0.3495)$ & (1.1239) & $(0.2440)$ & $(0.9523)$ & $(0.4730)$ & $(0.5018)$ & $(0.7677)$ & $(0.5702)$ \\
\hline NSLP & $-0.7943^{\mathrm{C}}$ & 0.5052 & $-0.9831^{B}$ & -0.2284 & $-2.0882^{\mathrm{A}}$ & $2.0434^{\mathrm{B}}$ & $-2.7704^{\mathrm{A}}$ & 1.3154 \\
\hline & $(0.4580)$ & $(0.9050)$ & $(0.3965)$ & (1.0983) & $(0.6923)$ & $(0.9732)$ & $(0.9244)$ & $(0.8559)$ \\
\hline WIC & -0.1741 & $-1.9025^{\mathrm{C}}$ & $-0.8401^{\mathrm{A}}$ & $1.2016^{\mathrm{C}}$ & $-1.1011^{\mathrm{B}}$ & $-1.0714^{\mathrm{C}}$ & $-1.5347^{\mathrm{B}}$ & 0.1927 \\
\hline & $(0.4501)$ & (1.0127) & $(0.2802)$ & $(0.7299)$ & $(0.4521)$ & $(0.5639)$ & $(0.6327)$ & $(0.4681)$ \\
\hline
\end{tabular}

Statistical significance is noted by ${ }^{\mathrm{A}}, \mathrm{B}$, and ${ }^{\mathrm{C}}$ at the $1 \%, 5 \%$, and $10 \%$ levels, respectively.

Numbers in parentheses are standard errors.

After controlling for the endogeneity, estimation results of, in particular, the food program variables differ from those reported in Table 2. In both binary and Rasch-scale models, coefficients of food programs now become negative and are statistically significant in most cases. The results indicate that the food programs have effectively reduced the probability of children's being food insecure as well as the severity of children's food insecurity, given children's demographics and their living environments. Comparing Table 2 and Table 3 clearly demonstrates the importance of addressing the endogeneity of food programs in specifying the food insecurity. The rest of results in Table 3 are mostly consistent with those reported in Table 2. 
Table 4 presents results from the pseudo panel data analysis in the simultaneous estimation framework.

Table 4. Estimates from Pseudo Panel Data Analysis with Simultaneous Equation Procedure

\begin{tabular}{|c|c|c|c|c|c|c|}
\hline \multirow[t]{4}{*}{ Variable } & \multicolumn{3}{|l|}{ Binary Model } & \multicolumn{3}{|c|}{ Rasch-Scale Model } \\
\hline & No Interaction & Interaction: & Interaction: & No Interaction & Interaction: & Interaction: \\
\hline & & Unmarried & Nonwhite & & Unmarried & Nonwhite \\
\hline & & *Income & *Income & & *Income & *Income \\
\hline \multirow[t]{2}{*}{ Intercept } & $-4.0747^{\mathrm{A}}$ & $-3.3139^{\mathrm{A}}$ & $-4.1505^{\mathrm{A}}$ & $4.9272^{\mathrm{A}}$ & $5.1405^{\mathrm{A}}$ & $5.4042^{\mathrm{A}}$ \\
\hline & $(1.0793)$ & $(0.9473)$ & (1.0009) & $(0.4003)$ & $(0.3894)$ & $(0.3953)$ \\
\hline \multirow[t]{2}{*}{ Schoolage } & 1.6419 & 1.4385 & $1.7692^{\mathrm{C}}$ & -0.0265 & -0.0647 & 0.0020 \\
\hline & $(1.0147)$ & $(0.9175)$ & $(0.9906)$ & $(0.3582)$ & $(0.3607)$ & $(0.3649)$ \\
\hline \multirow[t]{2}{*}{ Unmarried } & $1.0181^{\mathrm{B}}$ & -0.4471 & $0.7747^{\mathrm{C}}$ & $0.6539^{\mathrm{A}}$ & $0.8151^{\mathrm{A}}$ & $0.5133^{\mathrm{A}}$ \\
\hline & $(0.4672)$ & $(1.1082)$ & $(0.4720)$ & $(0.1994)$ & $(0.2702)$ & $(0.1985)$ \\
\hline \multirow[t]{2}{*}{ Income1 } & $2.7665^{\mathrm{A}}$ & & & $1.6860^{\mathrm{A}}$ & & \\
\hline & $(0.7022)$ & & & $(0.4023)$ & & \\
\hline \multirow[t]{2}{*}{ Income2 } & $2.6050^{\mathrm{A}}$ & & & $1.0584^{\mathrm{B}}$ & & \\
\hline & $(0.9389)$ & & & $(0.4555)$ & & \\
\hline \multirow[t]{2}{*}{ Income3 } & 1.0706 & & & 0.0977 & & \\
\hline & $(0.9581)$ & & & $(0.3954)$ & & \\
\hline \multicolumn{2}{|l|}{ Unmarried } & $2.4420^{\mathrm{B}}$ & & & -0.5481 & \\
\hline *Income1 & & $(1.2366)$ & & & $(0.4862)$ & \\
\hline \multicolumn{2}{|l|}{ Unmarried } & 4.2487 & & & -0.8410 & \\
\hline \multicolumn{2}{|l|}{ *Income2 } & $(2.9340)$ & & & $(0.8704)$ & \\
\hline \multicolumn{2}{|l|}{ Unmarried } & 1.2614 & & & -1.7809 & \\
\hline \multicolumn{2}{|l|}{ *Income3 } & $(1.7266)$ & & & $(1.8208)$ & \\
\hline \multicolumn{2}{|l|}{ Nonwhite } & & $2.4861^{\mathrm{A}}$ & & & $0.5295^{\mathrm{A}}$ \\
\hline \multicolumn{2}{|l|}{ *Income1 } & & $(0.6184)$ & & & $(0.2154)$ \\
\hline \multicolumn{2}{|l|}{ Nonwhite } & & $2.3242^{\mathrm{A}}$ & & & 0.2623 \\
\hline \multicolumn{2}{|l|}{ *Income2 } & & $(0.8333)$ & & & $(0.3843)$ \\
\hline \multicolumn{2}{|l|}{ Nonwhite } & & 0.9088 & & & -0.3033 \\
\hline \multicolumn{2}{|l|}{ *Income3 } & & $(0.8603)$ & & & $(0.3246)$ \\
\hline \multirow[t]{2}{*}{ Metropolitan } & 0.4127 & -0.1225 & -0.1821 & $0.4691^{\mathrm{B}}$ & $0.4052^{\mathrm{B}}$ & 0.1751 \\
\hline & $(0.5445)$ & $(0.4908)$ & $(0.5035)$ & $(0.1930)$ & $(0.1878)$ & $(0.2029)$ \\
\hline \multirow[t]{2}{*}{ Employed } & -0.4221 & -0.9265 & -0.7015 & -0.2672 & -0.3837 & $-0.4531^{\mathrm{C}}$ \\
\hline & $(0.6263)$ & $(0.6350)$ & $(0.6361)$ & $(0.2658)$ & $(0.2658)$ & $(0.2667)$ \\
\hline \multirow[t]{2}{*}{ SNAP } & -0.8835 & -1.4049 & -0.5361 & $-2.4307^{\mathrm{A}}$ & $-1.2772^{\mathrm{B}}$ & $-1.8695^{\mathrm{A}}$ \\
\hline & $(1.1491)$ & (1.0177) & (1.1387) & $(0.5699)$ & $(0.6250)$ & $(0.5648)$ \\
\hline \multirow[t]{2}{*}{ NSLP } & 0.7376 & 2.4998 & 1.0531 & -0.0076 & $-1.5953^{\mathrm{A}}$ & $-1.0845^{\mathrm{C}}$ \\
\hline & $(1.6345)$ & $(1.5617)$ & $(1.5252)$ & $(0.7057)$ & $(0.5851)$ & $(0.6024)$ \\
\hline \multirow[t]{2}{*}{ WIC } & 1.7237 & 1.7495 & 0.2977 & 0.4006 & 0.5605 & 0.2554 \\
\hline & $(2.4130)$ & $(2.4708)$ & $(2.5385)$ & $(0.9795)$ & $(0.9844)$ & $(0.9964)$ \\
\hline \multirow[t]{2}{*}{ Time } & 0.0263 & 0.0244 & 0.0292 & $0.0234^{\mathrm{A}}$ & $0.0139^{\mathrm{C}}$ & $0.0193^{\mathrm{A}}$ \\
\hline & $(0.0219)$ & $(0.0209)$ & $(0.0226)$ & $(0.0075)$ & $(0.0076)$ & $(0.0074)$ \\
\hline
\end{tabular}

Statistical significance is noted by ${ }^{\mathrm{A}},{ }^{\mathrm{B}}$, and ${ }^{\mathrm{C}}$ at the $1 \%, 5 \%$, and $10 \%$ levels, respectively.

Numbers in parentheses are standard errors.

For both binary and Rasch-scale models, the first column presents estimates and corresponding standard errors (in parentheses) from a model without interaction terms, while the second and the third columns show results from models with interaction terms between household income and Unmarried (Unmarried $=0$ if child lives with married couple; 1 otherwise), and between household income and Nonwhite (Nonwhite $=0$ if child is White and not Hispanic, 1 otherwise), respectively. The interaction terms are included in our specification to assess if effects of family structure and race on children's food insecurity differ by income group. Note that family structure, race, and income are major factors affecting binary and Rasch-Scale models in Table 2 and Table 3. In our pseudo-panel model, the race variable can be included only through interaction terms because the fixed effect model is used in this study and also the race variable (along with education, gender, and region) has been already used to generate cohorts.

From the binary probit regression with no interaction terms, we find that estimates of Unmarried, Income1, and Income 2 are statistically significant at least at the 5 percent level. Results indicate that children not living with married couple and living with lower income family (income/poverty is less than 1.3) tend to have higher probability of falling into food insecurity than those living with married couple and relatively higher income family (income/poverty is greater than or equal to1.8), respectively. Similar results are found from the Rasch-scale model with no interaction 
terms. Both binary and Rasch-scale models with interaction terms between family structure and household income levels (Unmarried*Income) show no statistical significance on estimates of the interaction terms (except Unmarried*Income1 of binary model). This result suggests that effects of family structure (in particular, the reference person's marital status) on children's food insecurity are not affected by household income. However, estimates of Nonwhite*income from the binary model are positive and statistically significant at least at the $1 \%$ level (except Nonwhite*Income3) and are decreasing with income level. The result indicates that relatively higher probability of being in food insecurity from non-white children (found in Table 2 and Table 3) decreases as household income increases. Similar pattern of income effect is found from the Rasch-scale model, but only the coefficient of Nonwhite*Income1 is statistically significant at the 1\% level. Effects of food programs on children's food insecurity have also been estimated. In the binary model, parameter estimates of all food programs are not statistically significant, and only the coefficient of SNAP is negative. However, unlike the binary model, the Rasch-scale model results in negative and statistically significant coefficients for SNAP and NSLP at least at the 10\% level (except the estimate of NSLP from the no interaction equation). This indicates that food programs, SNAP and NSLP, are effective in decreasing the extent of children's food insecurity over time.

\section{Conclusions}

Our study examined the impacts of food assistance programs, demographic characteristics of children, and socioeconomic status of households on children's food insecurity in U.S. Specifically, this study used probit and truncated regression models to investigate whether or not the food programs, SNAP, NSLP, and WIC, decreased the probability of children's being food insecure and the severity of children's food insecurity, while effects of children's age, gender, and race; family structure, income, and location; and reference person's education and employment status were also examined. The potential endogeneity problem, caused by reverse influence of food insecurity on participation of food programs, was addressed by the simultaneous equation procedure. Both annual cross-sectional and pseudo-panel analyses with fixed effect regressions were conducted in this study.

Results from probit and truncated regressions using annual cross-sectional data showed that children participating in food programs were mostly more likely to be food insecure and to be more severely food insecure without addressing the endogeneity problem of the food program variables. However, after correcting for the endogeneity problem, results from both binary and Rasch-scale models indicate that the food programs are mostly effective in reducing the probability of children's being food insecure as well as the severity of children's food insecurity. The pseudo panel analysis produced mixed results: from the binary model, no significant effect of food programs was found in reducing the probability of children's being in the food insecurity, while statistically significant effects of food programs, SNAP and NSLP, were found from the Rasch-scale model in reducing the extent of children's food insecurity problem over time. Overall, we found children's demographic characteristics and household socioeconomic status (living environments) also played significant role in determining both whether children were in food insecurity or not and the severity of children's food insecurity. Annual cross sectional analyses showed that non-white children and children living with sole-parent, low income and metropolitan households, and less educated and unemployed reference persons were more likely to fall into food insecurity and were likely to have more severe degree of food insecurity than white children and children living with married-parents, high income and suburban households, and more educated and employed reference persons, respectively. The pseudo panel analysis showed that effects of family structure, whether children live with sole-parent or married-parents, on children's food insecurity did not change with income levels. However, the analysis found that overall, non-white children's status of food insecurity problem was improved as household income increased.

Though our study found the effectiveness of some government-sponsored food programs in improving the status of children's food insecurity, it did not provide information about the effectiveness of food programs by either observed groups (for example, groups formed by children's demographics and their household characteristics) or any latent groups. The group analyses on the effectiveness of food programs might help answer such policy questions as: why is a food program more effective than others?, who should be the target group?, and what needs to be done to improve the programs? Another direction of extending the current study might be to consider measurement error problems due to the timing of food insecurity survey vs. food assistance receipt, misreporting the food insecurity status and the participation of food programs, and unknown (or unreported) household characteristics. Finally, the issue of measurement errors in forming cohorts for the pseudo panel analysis could be revisited. Several studies in the econometrics literature recently introduce both parametric and nonparametric procedures to address the measurement error problems.

\section{Footnotes}

1. The USDA generated the Rasch scale from a set of survey questions about the food insecurity following the item response theory, which will be further discussed in the data section.

2. The question was asked if the household received SNAP benefits for the past 12 months, while similar questions were 
asked if the household received NSLP and WIC benefits for the past 30 days.

3. Household income in the dataset is shown in ranges. Therefore, following Wilde \& Nord (2005) and Nord \& Romig (2006), the income variable in our study is represented by the ratio of annual household income (center of each income range is used) to poverty threshold of each household. Poverty thresholds are established by the U.S. Census Bureau on the basis of household income, household size, and number of children.

4. Metropolitan areas are central cities defined by the Office of Management and Budget. Residence is hypothesized to affect children's food insecurity by affecting living costs (Michael \& Citro, 1995).

\section{References}

Alaimo, K., Olson, C. M., Frongillo, Jr, E. A., \& Briefel, R. R. (2001). Food Insufficiency, Family Income, and Health in US Preschool and School-aged Children, American Journal of Public Health, 91(5),781. https://doi.org/10.2105/AJPH.91.5.781

Anderson, S. A. (1990). Core Indicators of Nutritional State for Difficult to Sample Populations, Journal of Nutrition, 120 (Suppl. 11), 1557S-1600S.

Aussenberg, R. A., \& Colello, K. J. (2016). Domestic Food Assistance: Summary of Programs, Congressional Research Service (7-5700), Washington, D. C.

Baker, J. L., \& Grosh, M. E. (1994). Poverty Reduction through Geographic Targeting: How Well Does It Work? World Development, 22(7), 983-995. https://doi.org/10.1016/0305-750X(94)90143-0

Bernard, J. T., Bolduc, D., \& Yameogo, N. D. (2011). A Pseudo-Panel Data Model of Household Electricity Demand, Resource and Energy Economics, 33(1), 315-325. https://doi.org/10.1016/j.reseneeco.2010.07.002

Bishop, J. A., Formby, J. P., \& Zeager, L. A. (1996). The Impact of Food Stamps on US Poverty in the 1980s: A Marginal Dominance Analysis, Economica, s141-s162. https://doi.org/10.2307/2554813

Blundell, R., Browning, M., \& Meghir, C. H. (1994). Consumer demand and the life-cycle allocation of household expenditures, The Review of Economic Studies, 61, 57-80. https://doi.org/10.2307/2297877

Borjas, G. (2004). Food Insecurity and Public Assistance, Journal of Public Economics. 88(7-8), 1421-1443. https://doi.org/10.1016/S0047-2727(02)00188-3

Coleman-Jensen, A., Nord, M., \& Singh, A. (2013). Household Food Security in the United States in 2012, Economic Research Report No. 155, ERS, USDA.

Collado, M. D. (1998). Estimating Binary Choice Models from Cohort Data, Investigaciones Economicas, 22(2), 259-276.

Cristofar, S. P., \& Basiotis, P. P. (1992). Dietary Intakes and Selected Characteristics of Women Ages 19-50 Years and Their Children Ages 1-5 Years by Reported Perception of Food Sufficiency, Journal of Nutrition Education, 24(2), 53-58. https://doi.org/10.1016/S0022-3182(12)80650-9

Deaton, A. (1985). Panel Data from Time Series of Cross-sections, Journal of Econometrics, 30,109-126. https://doi.org/10.1016/0304-4076(85)90134-4

Dixon, L. B., Winkleby, M. A., \& Radimer, K. L. (2001). Dietary Intakes and Serum Nutrients Differ between Adults from Food-insufficient and Food-sufficient Families: Third National Health and Nutrition Examination Survey, 1988-1994, Journal of Nutrition, 131(4), 1232-1246.

Dunifon, R., \& Kowaleski-Jones, L. (2003). The Influences of Participation in the National School Lunch Program and Food Insecurity on Child Well-being, Social Service Review, 77(1), 72-92. https://doi.org/10.1086/345705

Gleason, P. M., \& Suitor, C. W. (2003). Eating at School: How the National School Lunch Program Affects Children's Diets. American Journal of Agricultural Economics, 83(4), 1047-1061. https://doi.org/10.1111/1467-8276.00507

Gundersen, C., \& Gruber, J. (2001). The Dynamic Determinants of Food Insufficiency, in Second Food Security Measurement and Research Conference (Vol. 2, pp. 11-2). Food Assistance and Nutrition Research Report, ERS, USDA.

Gundersen, C., \& Oliveira, V. (2001). SNAP and Food Insufficiency, American Journal of Agricultural Economics, 83(4), 875-887. https://doi.org/10.1111/0002-9092.00216

Huffman, S. K., \& Jensen, H. H. (2008). Food Assistance Programs and Outcomes in the Context of Welfare Reform, Social Science Quarterly, 89, 95-115. https://doi.org/10.1111/j.1540-6237.2008.00523.x

Jensen, H. H. (2002). Food Insecurity and SNAP. American Journal of Agricultural Economics, 83(5), 1215-1228. https://doi.org/10.1111/1467-8276.00382 
Jolliffe, D., Gundersen, C., Tiehen, L., \& Winicki, J. (2005). Food Stamp Benefits and Child Poverty. American Journal of Agricultural Economics, 87(3), 569-581. https://doi.org/10.1111/j.1467-8276.2005.00748.x

Jyoti, D. F., Frongillo, E. A., \& Jones, S. J. (2005). Food Insecurity Affects School Children's Academic Performance, Weight Gain, and Social Skills, Journal of Nutrition, 135(12), 2831-2839.

Kabbani, N. S., \& Yazbeck, M. (2004). The Role of Food Assistance Programs and Employment Circumstances in Helping Households with Children Avoid Hunger, University of Wisconsin--Madison, Institute for Research on Poverty.

Maddala, G. (1983). Limited-Dependent and Qualitative Variables in Econometrics, Cambridge UK: Cambridge University Press. https://doi.org/10.1017/CBO9780511810176

Mallar, C. D. (1977). The Estimation of Simultaneous Probability Models, Econometrica, 45(7), 1717-1722. https://doi.org/10.2307/1913961

Michael, R. T., \& Citro, C. F. (Eds.) (1995). Measuring Poverty: A New Approach, National Research Council, National Academies Press, Washington, D.C.

Moffit, R. (1993). Identification and Estimation of Dynamic Models with a Time Series of Repeated Cross-sections, Journal of Econometrics, 59(1-2), 99-123. https://doi.org/10.1016/0304-4076(93)90041-3

Nord, M., \& Golla, A. M. (2009). Does SNAP Decrease Food Insecurity?: Untangling the Self-selection Effect, Economic Research Reporting No. ERR-85, ERS/USDA.

Nord, M., \& Romig, K. (2006). Hunger in the Summer: Seasonal Food Insecurity and the National School Lunch and Summer Food Service Programs, Journal of Children \& Poverty, 12(2), 141-158. https://doi.org/10.1080/10796120600879582

Ranney, C. K., \& Gómez, M. I. (2010). Food Stamps, Food Insufficiency and Health of the Elderly, Working paper WP-2010-15, Charles H. Dyson School of Applied Economics and Management, Cornell University.

Rasch, G. (1960/1980). Probabilistic Models for Some Intelligence and Attainment Tests, Danish Institute for Educational Research, Copenhagen; expanded edition (1980) with foreword and afterword by B.D. Wright. Chicago: The University of Chicago Press.

Ratcliffe, C., McKernan, S. M., \& Zhang, S. (2011). How much does the Supplemental Nutrition Assistance Program Reduce Food Insecurity? American Journal of Agricultural Economics, 93(4), 1082-1098. https://doi.org/10.1093/ajae/aar026

Reed, A. J., \& Levedahl, J. W. (2010). Food Stamps and the Market Demand for Food. American Journal of Agricultural Economics, 92(5),1392-1400. https://doi.org/10.1093/ajae/aaq069

Ribar, D., \& Hamrick, K. (2003). Dynamics of Poverty and Food Sufficiency, Food Assistance and Nutrition Research Report No. 33, ERS, USDA.

Rose, D. (1999). Economic Determinants and Dietary Consequences of Food Insecurity in the United States, Journal of Nutrition, 129(2), 517s-520s.

U.S. Census Bureau, Current Population Survey, Annual Social and Economic Supplements (CPS-ASEC); Available at http://www.census.gov/programs-surveys/cps/data-detail.html, Accessed on July 11, 2014.

U.S. Census Bureau, Current Population Survey, Food Security Supplements (CPS-FSS); Available at: http://www.ers.usda.gov/data-products/food-security-in-the-united-states.aspx, Accessed on July 11, 2014.

U.S. Department of Agriculture, Economic Research Service (USDA/ERS), SNAP Policy Database; Available at: http://www.ers.usda.gov/data-products/snap-policy-database.aspx Accessed on: July 14, 2014.

Verbeek, M., \& Nijman, T. E. (1992). Can Cohort Data be Treated as Genuine Panel Data? Empirical Economics, 17, 9-23. https://doi.org/10.1007/BF01192471

Vereecken, C. A., \& Maes, L. (2003). A Belgian Study on the Reliability and Relative Validity of the Health Behaviour in School-Aged Children Food-frequency Questionnaire, Public Health Nutrition, 6(6), 581-588. https://doi.org/10.1079/PHN2003466

Weinreb, L., Wehler, C., Perloff, J., Scott, R., Hosmer, D., Sagor, L., \& Gundersen, C. (2002). Hunger: Its Impact on Children's Health and Mental Health, Pediatrics, 110(4), e41. https://doi.org/10.1542/peds.110.4.e41

Wilde, P., \& Nord, M. (2005). The Effect of Food Stamps on Food Security: A Panel Data Approach, Applied Economics and Perspective, 27(3), 425-432. https://doi.org/10.1111/j.1467-9353.2005.00239.x

Yen, S. T., Andrews, M., Chen, Z., \& Eastwood, D. B. (2008). Food Stamp Program Participation and Food Insecurity: 
An Instrumental Variables Approach. American Journal of Agricultural Economics, 90(1), 117-132. https://doi.org/10.1111/j.1467-8276.2007.01045.x

\section{Copyrights}

Copyright for this article is retained by the author(s), with first publication rights granted to the journal.

This is an open-access article distributed under the terms and conditions of the Creative Commons Attribution license which permits unrestricted use, distribution, and reproduction in any medium, provided the original work is properly cited. 